\title{
Limiting factors for anaerobic digestion of olive mill wastewater blends under mesophilic and thermophilic conditions
}

\author{
Demetrio Antonio Zema, ${ }^{1}$ Giovanni Zappia, ${ }^{1}$ Souraya Benalia, ${ }^{1}$ Giuseppe Zimbalatti, ${ }^{1}$ Enzo Perri, ${ }^{2}$ \\ Elena Urso, ${ }^{2}$ Vincenzo Tamburino, ${ }^{1}$ Bruno Bernardi ${ }^{1}$ \\ ${ }^{1}$ Dipartimento di Agraria, Università degli Studi Mediterranea di Reggio Calabria, Reggio Calabria; ${ }^{2}$ Centro di ricerca \\ per l'olivicoltura e l'industria olearia (CREA-OLI), Rende (CS), Italy
}

\begin{abstract}
Experimental trials of anaerobic digestion of olive mill wastewater (OMW) blended with other agro-industrial by-products were carried out to evaluate biogas production and sensitivity of the process to inhibiting compounds. Blends containing different percentages of OMW, digested liquid manure, and citrus peel were subjected to a batch anaerobic digestion process under both mesophilic and thermophilic conditions. The results showed that blends with percentages of OMW higher than $20 \%(\mathrm{v} / \mathrm{v})$ had low methane yields due high concentrations of polyphenols (PPs) and/or volatile fatty acids (concentrations above $0.8 \mathrm{~g} \mathrm{~kg}^{-1}$ and 2.4 $\mathrm{g} \mathrm{L}^{-1}$, respectively). The addition of other substrates such as citrus peel may have induced synergic inhibiting effects of PPs and essential oils (EO) on microbial growth. Thermophilic processes were more sensitive to these inhibiting compounds than mesophilic processes. The results of this study suggest that reducing PPs and EO concentrations in blends subject to anaerobic
\end{abstract}

Correspondence: Souraya Benalia, Dipartimento di Agraria, Università degli Studi Mediterranea di Reggio Calabria, Loc. Feo di Vito, 89122 Reggio Calabria, Italy.

E-mail: soraya.benalia@unirc.it

Key words: Agro-industrial by-product; anaerobic digestion; biogas; inhibiting compounds; methane yield; polyphenols.

Acknowledgements: the present research was realised with the support of the National Operative Project PON Ricerca e Competitività 20072013, PON01_01545 OLIOPIU' 'Sistemi tecnologici avanzati e processi integrati nella filiera olivicola per la valorizzazione dei prodotti e dei sottoprodotti, lo sviluppo di nuovi settori e la creazione di sistemi produttivi ecocompatibili', funded by the Italian Ministry of Education, University and Research.

Contributions: all the authors contributed equally to the present research.

Received for publication: 18 September 2017.

Accepted for publication: 13 January 2018.

CCopyright D.A. Zema et al., 2018

Licensee PAGEPress, Italy

Journal of Agricultural Engineering 2018; XLIX:792

doi:10.4081/jae.2018.792

This article is distributed under the terms of the Creative Commons Attribution Noncommercial License (by-nc 4.0) which permits any noncommercial use, distribution, and reproduction in any medium, provided the original author(s) and source are credited. digestion below the inhibiting concentrations of $0.6 \mathrm{~g} \mathrm{~L}^{-1}$ and 0.5 $\mathrm{g} \mathrm{kg}^{-1}$, respectively, is suitable. Additionally, it is advisable to maintain the volatile fatty acids content below $2 \mathrm{~g} \mathrm{~L}^{-1}$ to avoid its evident toxic effects on the growth of microorganisms in biochemical processes.

\section{Introduction}

Energy production from agro-industrial residues (for example, olive mill wastewater, husk, and citrus peel) is a feasible approach for their valorisation. This assures sustainable management of agro-industrial residues, thereby avoiding the environmental problems associated with their disposal on soil and in water bodies (Bernardi et al., 2017). Additionally, it allows the integration of agro-industry profits from self-sustaining energy production and national subsidies for renewable energy. Anaerobic digestion for methane production is one of the most promising energy conversion processes.

In the Mediterranean agricultural areas, olive mills produce high volumes of wastewater (OMW) annually. Therefore, the organic matter present in OMW would theoretically generate a large amount of bioenergy. However, OMW cannot be used alone in anaerobic digestion processes because of its low $\mathrm{pH}$, high polyphenols (PPs) and volatile fatty acids (VFA) contents, and low ammonium nitrogen content (Fezzani and Ben Cheikh, 2007).

The highly acidic pH (3-6) of OMW (Borja et al., 2006) and the shortage of nitrogen can be easily overcome (for example, by adding carbonate and/or urea) in anaerobic processes. The presence of PPs, in concentrations ranging between 0.5 and $24 \mathrm{~g} \mathrm{~L}^{-1}$ (Borja et al., 2006), significantly reduces or even completely inhibits biogas production. This is because PPs exert toxic effects on microorganisms by uncoupling oxidative phosphorylation or inhibiting electron transport (Escher et al., 1996). A unanimous value of the PPs concentration that inhibits bacterial growth during anaerobic digestion of OMW is not available in scientific literature. Generally, VFA concentrations between $4 \mathrm{~g} \mathrm{~L}^{-1}$ and $10 \mathrm{~g}$ $\mathrm{L}^{-1}$ in OMW (Fezzani and Ben Cheikh, 2007) are toxic since the proportion of VFA in their undissociated form increases. Volatile fatty acids can flow freely through the cell membrane and dissociate inside the cell thereby reducing $\mathrm{pH}$ and disrupting homoeostasis (Appels et al., 2008). Additionally, in anaerobic digesters, VFA can enhance the inhibiting effect of low $\mathrm{pH}$ on methane production and VFA degradation (Appels et al., 2008). To carry out a balanced anaerobic digestion of OMW, concentrations of PPs must be reduced through extraction for recovery of added-value compounds. However, this pre-treatment is generally expensive and is therefore not sustainable for small factories. A more sustainable solution is the co-digestion of OMW with other agro-industrial or livestock biomasses available in the surroundings of factories. 
Blending OMW with other substrates enables to regulate acidity, dilutes PPs and VFA and alleviates the shortage of nitrogen in OMW. This process is of particular interest because it does not require addition of chemical substances, which is generally not economical and environmentally sustainable (Angelidaki and Ahring, 1997; Fezzani and Ben Cheikh, 2007). However, the optimal percentages of each substrate in the blend for anaerobic digesters require evaluation (Zema, 2017). This is particularly required for biogas plants since they are fed with blends of OMW and other agro-industrial residues, which may contain toxic compounds (for example, essential oils in citrus waste and tannins in winery residues).

Several studies on the effects PPs on anaerobic digestion of OMW are available in literature; however, data obtained are generally dispersed because different conditions and blends were used in the anaerobic digestion processes of different studies (GonzàlesGonzàles and Cuadros, 2015). The number of studies that have investigated the concentrations of PPs and VFA that inhibit anaerobic digestion of OMW is lower than that on the effects of these compounds on anaerobic digestion processes. According to Fedorak and Hrudey (1984) and Borja et al. (1996), the inhibiting concentration of PPs is about $0.6-2 \mathrm{~g} \mathrm{~L}^{-1}$ and VFA exert inhibiting effects on biogas production at concentrations above $2 \mathrm{~g} \mathrm{~L}^{-1}$. According to Siegert and Banks (2005) and Appels et al. (2008), these inhibiting effects are particularly evident at VFA concentrations above $6-8 \mathrm{~g} \mathrm{~L}^{-1}$.

This study contributes to filling this research gap through an evaluation of the biochemical process and an investigation of the limiting factors of anaerobic co-digestion of OMW. Batch tests of methane production from OMW blended with an inoculum of digested liquid manure (DLM) were carried out. The objectives of these tests were: i) identify the optimal percentage of OMW in the blend with respect to the inhibiting concentrations of PPs and VFA; ii) detect possible synergic inhibiting effects of PPs in OMW and essential oils (toxic for methanogenic bacteria) in citrus peel (CP), which is an agro-industrial residue that is widely diffused in the Mediterranean Basin. Experimental tests were carried out under both mesophilic and thermophilic conditions to evaluate the effect of temperature on biogas/methane yields of the blends.

\section{Materials and methods}

\section{Experimental setup}

Two series of anaerobic batch tests were carried out under mesophilic and thermophilic conditions.
The first series consisted of five tests. In the first three tests, OMW was blended with DLM as inoculum at different concentrations to evaluate the decrease in biogas/methane yields with increasing PPs concentrations. A fourth test was carried with DLM and OMW blend, in which $10 \%$ of OMW volume was replaced with the same volume of CP. The aim of this test was to verify whether the presence of inhibiting compounds [PPs in OMW and essential oils (EO) in $\mathrm{CP}$ ] below their respective inhibiting concentrations impedes anaerobic co-digestion of OMW and $\mathrm{CP}$ and reduce biogas/methane yields. The inhibiting concentrations of PPs and EO reported in literature (Forgács, 2012; Wikandari et al., 2014) were used in the experimental tests. A fifth test was performed with a blend of DLM $(80 \% \mathrm{v} / \mathrm{v})$ and CP $(20 \% \mathrm{v} / \mathrm{v})$; EO concentration in this blend was higher than the inhibiting concentration.

The second series of tests was carried out under thermophilic conditions with the following blends: DLM (80\% v/v)/OMW $(20 \% \mathrm{v} / \mathrm{v})$, DLM $(80 \% \mathrm{v} / \mathrm{v}) / \mathrm{CP}(20 \% \mathrm{v} / \mathrm{v})$, and DLM $(70 \%$ $\mathrm{v} / \mathrm{v}) / \mathrm{OMW}(20 \% \mathrm{v} / \mathrm{v}) / \mathrm{CP}(10 \% \mathrm{v} / \mathrm{v})$. The DLM $(50 \% \mathrm{v} / \mathrm{v}) / \mathrm{OMW}$ $(50 \% \mathrm{v} / \mathrm{v})$ and DLM $(70 \% \mathrm{v} / \mathrm{v}) / \mathrm{OMW}(30 \% \mathrm{v} / \mathrm{v})$ blends, with which partial or complete inhibition was observed in the first series of tests were not used in the experimental trials under thermophilic conditions since thermophilic anaerobic digestion is more sensitive to inhibiting compounds than mesophilic anaerobic digestion (Levén and Schnürer, 2005; Fezzani and Ben Cheikh, 2007). A summary of the blend compositions tested under mesophilic and thermophilic anaerobic digestion is reported in Table 1.

Prior to the co-digestion experimental trials, a blank experiment using only DLM as substrate was performed.

\section{Characterisation of substrates and blends}

Digested liquid manure was drawn from a large-scale anaerobic reactor, supplied with cow liquid manure. Olive mill wastewater was collected from a three-phase centrifugal system used for extracting oil from olive cultivar Ottobratica, which is a typical olive cultivar in Calabria (Southern Italy). Citrus peel generated by orange juice extractors of a medium-size industry, was used in this study without further processing.

Each substrate was characterised prior to the digestion process. The contents of dry matter (DM, after oven drying at $105^{\circ} \mathrm{C}$ for 24 h), total volatile solids (TVS, after incineration at $600^{\circ} \mathrm{C}$ in a muffle furnace for $6 \mathrm{~h}$ ), and VFA were determined according to the respective American Public Health Association (APHA) methods (APHA, 1998). The concentration of PPs in OMW was determined by the Folin-Ciocalteu (1927) method using a spectrophotometer (PerkinElmer, Lambda 35 UV-VIS). The concentration of EO in CP was determined with the method of Scott and Veldhuis (1966). Values of $\mathrm{pH}$ were determined with a $\mathrm{pH}$ meter (Hach-Lange

Table 1. Composition of the blends tested under mesophilic and thermophilic anaerobic digestion.

\begin{tabular}{|c|c|c|c|c|}
\hline Temperature conditions & Test & Digested liquid manure \% (v/v) & Olive mill wastewater $\%(\mathrm{v} / \mathrm{v})$ & Citrus peel \% (v/v) \\
\hline Mesophilic conditions $\left(37^{\circ} \mathrm{C}\right)$ & $\begin{array}{l}1 \\
2 \\
3 \\
4 \\
5\end{array}$ & $\begin{array}{l}50 \\
70 \\
80 \\
70 \\
80\end{array}$ & $\begin{array}{c}50 \\
30 \\
20 \\
20 \\
0\end{array}$ & $\begin{array}{c}0 \\
0 \\
0 \\
10 \\
20\end{array}$ \\
\hline Thermophilic conditions $\left(52^{\circ} \mathrm{C}\right)$ & $\begin{array}{l}1 \\
2 \\
3\end{array}$ & $\begin{array}{l}80 \\
80 \\
70\end{array}$ & $\begin{array}{c}20 \\
0 \\
20\end{array}$ & $\begin{array}{c}0 \\
20 \\
10\end{array}$ \\
\hline
\end{tabular}


HQ40). All measurements were obtained in triplicates. The physico-chemical properties of the substrates are reported in Table 2.

\section{Test description}

Each experimental trial was carried out in duplicate in a batch reactor with a volume of $2 \mathrm{~L}$, containing $1 \mathrm{~L}$ of blend. Each reactor was hermetically sealed and placed in a climatic chamber for 25 days at constant mesophilic $\left(37^{\circ} \mathrm{C}\right)$ and thermophilic $\left(52^{\circ} \mathrm{C}\right)$ temperatures. The volume of biogas produced was monitored daily by connecting each reactor to a $2.5 \mathrm{~L}$ bottle, hydraulically and hermetically. The volume of biogas produced in the reactor displaced an equal volume of water from the bottle, which was collected in a graduated tank. The water level in this graduated tank corresponded to the volume of biogas produced. Methane contents in daily biogas samples from each reactor were measured using a gas chromatograph (Agilent, GC6890), which had been calibrated with known concentrations of methane.

All blends were allowed to acclimatise to both the mesophilic and thermophilic conditions for $24 \mathrm{~h}$ before measurements were taken.

Biogas and methane yields have been normalised to normal litres (dry gas, $\mathrm{T}=0^{\circ} \mathrm{C}, \mathrm{P}=1013 \mathrm{hPa}$ ), according to the standard procedures described in the VDI 4630 (2006) as carried out by Dinuccio et al. (2010).

The statistical significance of the differences in daily biogas and methane yields were analysed by a one-way analysis of variance ANOVA with XLSTAT software $(\mathrm{P}<0.05)$.

\section{Results and discussion}

\section{Mesophilic tests}

Blends of digested liquid manure and olive mill wastewater with different concentrations of polyphenols

The blank experiment (using only inoculum) showed very low biogas production. Moreover, no biogas production was observed after the first three days.

The results of the trials performed on blends of DLM and OMW after 25 days showed (Tables 3 and 4): i) the DLM (50\% $\mathrm{v} / \mathrm{v}) / \mathrm{OMW}(50 \% \mathrm{v} / \mathrm{v})$ blend showed very low total methane production (less than $0.73 \mathrm{NL} \mathrm{L}^{-1}$ of blend, corresponding to 0.016 $\mathrm{Nm}^{3} \mathrm{kgTVS}^{-1}$ ); ii) a higher methane production (about $2.4 \mathrm{NL} \mathrm{L}^{-1}$ of blend, corresponding to about $0.067 \mathrm{Nm}^{3} \mathrm{kgTVs}^{-1}$ ) was observed with the DLM $(70 \% \mathrm{v} / \mathrm{v}) / \mathrm{OMW}(30 \% \mathrm{v} / \mathrm{v})$ blend.

In blends with an OMW content that is equal to or higher than $30 \%$ and PPs and VFA initial concentrations more than $0.8 \mathrm{~g} \mathrm{~kg}^{-1}$ and $2.4 \mathrm{~g} \mathrm{~L}^{-1}$, respectively, reduction in biogas production rate was observed after $12-15$ days. The biogas produced by the DLM (50\% $\mathrm{v} / \mathrm{v}) / \mathrm{OMW}(50 \% \mathrm{v} / \mathrm{v})$ blend contained less than $45 \%$ of methane. This percentage was further reduced to $25 \%$ in the last ten days of the experiment (Figure 1). After 15 days the methane yield was only $1-2 \%$ of the total production (Table 3 ).

Low methane yields may be because of the high concentrations of TVS, PPs, and VFA (Table 2). However, the high concentration

Table 2. Initial characterisation of substrates and blends subject to anaerobic digestion in the experimental tests.

\begin{tabular}{|c|c|c|c|c|c|c|c|c|c|}
\hline \multicolumn{2}{|c|}{ Parameter } & \multicolumn{3}{|c|}{ Substrate } & \multirow[b]{2}{*}{ DLM50/0MW50 } & \multicolumn{3}{|c|}{ Blend** } & \multirow[b]{2}{*}{ DLM70/0MW20/CP10 } \\
\hline & & DLM & OMW & $\mathrm{CP}$ & & DLM70/0MW30 & DLM80/0MW20 & DLM80/CP20 & \\
\hline \multirow[t]{2}{*}{ DM } & $\mathrm{g} \mathrm{kg}^{-1 *}$ & 32.3 & 74.5 & 221 & 53.8 & 44.7 & 41.0 & 69.1 & 60.2 \\
\hline & $\%$ & 3.23 & 7.45 & 22.1 & 5.4 & 4.5 & 4.1 & 6.9 & 6.0 \\
\hline $\mathrm{pH}$ & - & 7.9 & 4.5 & 3.6 & 7.1 & 7.4 & 7.5 & 6.9 & 6.9 \\
\hline VFA & $\mathrm{g} \mathrm{kg}^{-1 *}$ & 0.6 & 6.5 & 2.0 & 4.4 & 2.4 & 1.9 & 0.7 & 1.8 \\
\hline TVS & $\mathrm{g} \mathrm{kg}^{-1 *}$ & 23.9 & 64.1 & 215 & 44.6 & 35.8 & 32.1 & 61.2 & 49 \\
\hline PPs & $\mathrm{g} \mathrm{kg}^{-1 *}$ & 0 & 2.8 & 0 & 1.4 & 0.8 & 0.6 & 0 & 0.6 \\
\hline EO & $\mathrm{g} \mathrm{kg}^{-1 *}$ & 0 & 0 & 5.2 & 0.0 & 0.0 & 0.0 & 1.0 & 0.5 \\
\hline
\end{tabular}

*Measured on raw substrate; **the number after the substrate indicates its percentage in the blend: \% (v/v). DLM, digested liquid manure; OMW, olive mill wastewater; CP, citrus peel; DM, dry matter; VFA, volatile fatty acids; TVS, total volatile solids; PPs, polyphenols; EO, essential oils.

Table 3. Total biogas and methane yields under standard conditions (T: $0^{\circ} \mathrm{C}, \mathrm{P}: 1013 \mathrm{hPa}$ ) (in NL $\mathrm{L}^{-1}$ of blend) in the blends tested under mesophilic and thermophilic anaerobic digestion.

\begin{tabular}{|c|c|c|c|c|}
\hline \multirow{2}{*}{$\begin{array}{l}\text { Blend } \\
\text { Mesophilic conditions }\left(37^{\circ} \mathrm{C}\right)\end{array}$} & \multicolumn{2}{|c|}{ Total biogas yield $\left(\mathrm{NL} \mathrm{L}^{-1}\right)$} & \multicolumn{2}{|c|}{ Total methane yield (NL L'-1) } \\
\hline & After 15 days & After 25 days & After 15 days & After 25 days \\
\hline DLM50/OMW50 & 3.23 & 3.27 & 0.71 & 0.72 \\
\hline DLM70/OMW30 & 6.13 & 6.31 & 2.36 & 2.40 \\
\hline DLM80/OMW20 & 7.69 & 11.61 & 3.49 & 5.99 \\
\hline DLM80/CP20 & 11.89 & 12.70 & 5.95 & 6.50 \\
\hline DLM70/OMW20/CP10 & 8.21 & 8.96 & 4.33 & 4.83 \\
\hline \multicolumn{5}{|c|}{ Thermophilic conditions $\left(52^{\circ} \mathrm{C}\right)$} \\
\hline DLM80/OMW20 & 3.20 & 3.50 & 2.02 & 2.22 \\
\hline DLM80/CP20 & 6.41 & 7.21 & 3.78 & 4.28 \\
\hline DLM70/OMW20/CP10 & 2.47 & 3.39 & 1.26 & 1.74 \\
\hline
\end{tabular}

DLM, digested liquid manure; OMW, olive mill wastewater; CP, citrus peel. 
of TVS may not be the cause of low methane yields since both methane yields and TVS concentrations of the DLM $(80 \% \mathrm{v} / \mathrm{v}) / \mathrm{CP}$ $(20 \% \mathrm{v} / \mathrm{v})$ and DLM $(70 \% \mathrm{v} / \mathrm{v}) / \mathrm{OMW}(20 \% \mathrm{v} / \mathrm{v}) / \mathrm{CP}(10 \% \mathrm{v} / \mathrm{v})$ blends (discussed below) were higher than those of the DLM $(50 \%$ $\mathrm{v} / \mathrm{v}) / \mathrm{OMW}(50 \% \mathrm{v} / \mathrm{v})$ and DLM (70\% v/v)/OMW (30\% v/v) blends (Table 2). This has been confirmed by previous studies. Angelidaki and Ahring (1997) observed inhibition of methane production using undiluted OMW blends with TVS concentrations higher than 48-50 $\mathrm{g} \mathrm{L}^{-1}$, while Kougias et al. (2014) did not observe such an inhibition even at a TVS concentration of about 55 $\mathrm{g} \mathrm{L}^{-1}$. Additionally, other researchers (Yi et al., 2014) did not observe inhibiting effects of TVS at concentrations of about 50$100 \mathrm{~g} \mathrm{~L}^{-1}$ in blends of food waste.

Concentrations of PPs and VFA in the DLM (50\% v/v)/OMW $(50 \% \mathrm{v} / \mathrm{v})$ and DLM $(70 \% \mathrm{v} / \mathrm{v}) / \mathrm{OMW}(30 \% \mathrm{v} / \mathrm{v})$ blends were higher than the inhibiting concentrations of PPs $\left(0.6-2 \mathrm{~g} \mathrm{~L}^{-1}\right)$, reported by Borja et al. (1996) and Fedorak and Hrudey (1984), and of VFA $\left(2 \mathrm{~g} \mathrm{~L}^{-1}\right)$, reported by Siegert and Banks (2005) and Appels et al. (2008), respectively. This suggests that the prevalence of acidogenic bacteria may be because of the increase in VFA content [from 4.5 to $11.7 \mathrm{~g} \mathrm{~L}^{-1}$ of raw substrate in DLM (50\% v/v)/OMW $(50 \% \mathrm{v} / \mathrm{v})$ and from 2.4 to $8.6 \mathrm{~g} \mathrm{~L}^{-1}$ of raw substrate in DLM $(70 \%$ $\mathrm{v} / \mathrm{v}) / \mathrm{OMW}(30 \% \mathrm{v} / \mathrm{v})]$ and the decrease in $\mathrm{pH}$ [from 7.1 at the start of the trial to 5.1 at the end of the trial for DLM $(50 \% \mathrm{v} / \mathrm{v}) / \mathrm{OMW}$ $(50 \% \mathrm{v} / \mathrm{v})$ and from 7.4 to 5.6 for DLM $(70 \% \mathrm{v} / \mathrm{v}) / \mathrm{OMW}(30 \%$ $\mathrm{v} / \mathrm{v})]$. Acidogenic bacteria are more resistant than methanogenic bacteria, which are extremely sensitive to $\mathrm{pH}$ in the range $6.5-8$, (Gelegenis et al., 2007) thereby resulting in reduced methane production rates.

Higher biogas production rates can be obtained by reducing the concentrations of PPs and VFA below $0.56 \mathrm{~g} \mathrm{~L}^{-1}$ [as suggested by Fedorak and Hrudey (1984) and Borja et al. (1996)] and $2 \mathrm{~g} \mathrm{~L}^{-1}$ [as suggested by Siegert and Banks (2005) and Appels et al. (2008)], respectively. The daily biogas production rate of the DLM $(80 \%$ $\mathrm{v} / \mathrm{v}) / \mathrm{OMW}(20 \% \mathrm{v} / \mathrm{v})$ blend with OMW accounting for $20 \%$ of the blend volume was almost higher than $0.40 \mathrm{NL} \mathrm{L}^{-1}$ of blend in the first 20 days (Figure 1A). Except for the first three days, the methane content of biogas produced was above $40 \%$. The total volume of methane produced in 25 days $\left(5.99 \mathrm{NL} \mathrm{L}^{-1}\right.$ of blend, corresponding to about $0.187 \mathrm{Nm}^{3} \mathrm{kgTVS}^{-1}$, Table 4) was about three and ten times higher than the volumes of methane produced from the DLM (70\% v/v)/OMW (30\% v/v) and DLM (50\% v/v)/OMW $(50 \% \mathrm{v} / \mathrm{v})$ blends, respectively. Unlike for the DLM $(50 \%$ $\mathrm{v} / \mathrm{v}) / \mathrm{OMW}(50 \% \mathrm{v} / \mathrm{v})$ and DLM $(70 \% \mathrm{v} / \mathrm{v}) / \mathrm{OMW}(30 \% \mathrm{v} / \mathrm{v})$ blends, the methane yield for the DLM $(80 \% \mathrm{v} / \mathrm{v}) / \mathrm{OMW}(20 \% \mathrm{v} / \mathrm{v})$ blend during the last ten days of the experiment was $40 \%$ of the total amount produced. In this blend, OMW is highly diluted. This may have reduced the inhibiting effects of toxic compounds on methanogenic bacteria (indicated by the constant methane content of biogas).

The blends with 20\% OMW show a smaller increase in VFA concentration (1.9 and $2.8 \mathrm{~g} \mathrm{~L}^{-1}$ of raw substrate at the beginning and end of the trial, respectively) than the blends with OMW content higher than 20\% [DLM (50\% v/v)/OMW (50\% v/v) and DLM $(70 \% \mathrm{v} / \mathrm{v}) / \mathrm{OMW}(30 \% \mathrm{v} / \mathrm{v})]$ after the $12^{\text {th }}$ day (Figure $\left.1 \mathrm{~A}\right)$. Therefore, we can conclude that for blends with an OMW content of $20 \%$, the reactor conditions are more favourable for methanogenesis after the $12^{\text {th }}$ day. Moreover, the $\mathrm{pH}$ of this blend was almost stable ( 7.5 and 7.3 at the beginning and end of the trial, respectively). The methane yields of the tested blends were compared to the methane yields observed in other studies. Kougias et al. (2014) carried out co-digestion batch tests of OMW (40\% v/v) and swine manure $(60 \% \mathrm{v} / \mathrm{v})$ under mesophilic conditions; the highest cumulative methane yield $\left(0.373 \mathrm{Nm}^{3} \mathrm{kgTVS}^{-1}\right)$ was obtained after 40 days. The methane yields after 15 days of the blends tested in our study were compared with their results. We made the following observations: i) the methane yield of DLM $(50 \% \mathrm{v} / \mathrm{v}) / \mathrm{OMW}(50 \% \mathrm{v} / \mathrm{v})\left(0.016 \mathrm{Nm}^{3} \mathrm{kgTvs}^{-1}\right.$, Table 4$)$ is similar to the methane yield in Kougias et al. (2014) $\left(0.020 \mathrm{Nm}^{3}\right.$ $\left.\mathrm{kgTVS}^{-1}\right)$; ii) the methane yield of DLM $(70 \% \mathrm{v} / \mathrm{v}) / \mathrm{OMW}(30 \%$ $\mathrm{v} / \mathrm{v})\left(0.066 \mathrm{Nm}^{3} \mathrm{kgTVS}^{-1}\right.$, Table 4) is half the methane yield in Kougias et al. (2014) $\left(0.130 \mathrm{Nm}^{3} \mathrm{kgTVS}^{-1}\right)$; iii) the methane yield of DLM $(80 \% \mathrm{v} / \mathrm{v}) / \mathrm{OMW}(20 \% \mathrm{v} / \mathrm{v})\left(0.109 \mathrm{Nm}^{3} \mathrm{kgTVs}^{-1}\right.$, Table 4$)$ is noticeably higher than that in Kougias et al. (2014) $\left(0.040 \mathrm{Nm}^{3}\right.$ $\mathrm{kgTVs}^{-1}$ ). In a previous study, the same group of researchers (Kougias et al., 2010) observed a noticeable increase in the methane yields of their blends between the $15^{\text {th }}$ and $25^{\text {th }}$ day. Methane yield of their blend with $20 \%$ of OMW is equal to the methane yield observed in our test with DLM (80\% v/v)/OMW $(20 \% \mathrm{v} / \mathrm{v})\left(0.187 \mathrm{Nm}^{3} \mathrm{kgTVs}^{-1}\right.$, Table 4$)$. The methane yields, in their study, of blends with OMW contents of $30 \%\left(0.280 \mathrm{Nm}^{3}\right.$
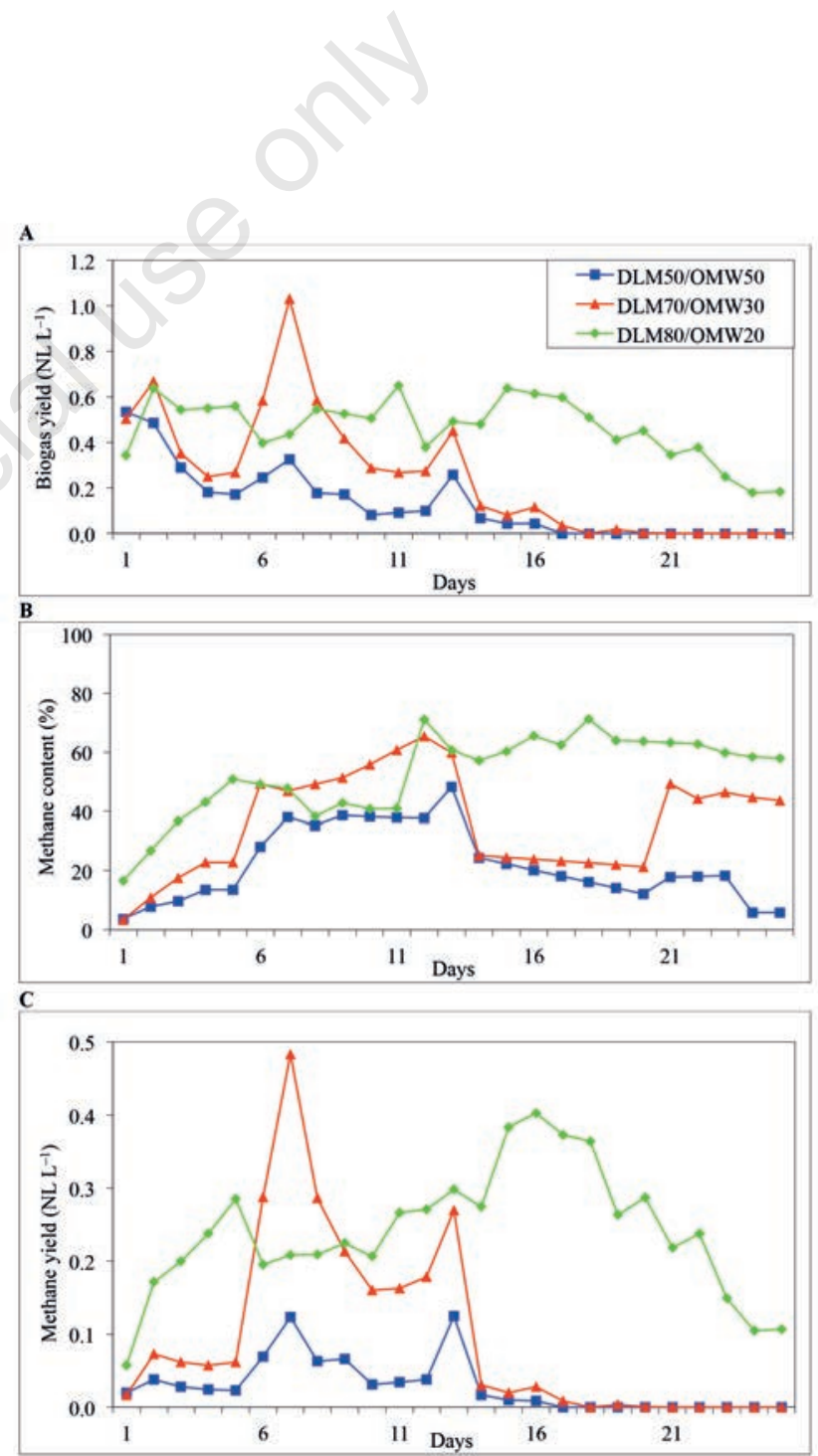

Figure 1. Biogas yield (A), methane content in biogas (B), and methane yield $(C)$ under standard conditions $\left(\mathrm{T}: 0^{\circ} \mathrm{C}, \mathrm{P}: 1013\right.$ $\mathrm{hPa}$ ), from anaerobic digestions of different blends of OMW under mesophilic conditions $\left(37^{\circ} \mathrm{C}\right)$. The number after the substrate indicates its percentage in the blend volume: $\%(v / v)$. 
$\left.\mathrm{kgTVs}^{-1}\right)$ and $50 \%\left(0.080 \mathrm{Nm}^{3} \mathrm{kgTVs}^{-1}\right)$ were noticeably higher than the methane yields, of DLM (70\% v/v)/OMW (30\% v/v) and DLM $(50 \% \mathrm{v} / \mathrm{v}) / \mathrm{OMW}(50 \% \mathrm{v} / \mathrm{v})$, respectively, $0.067 \mathrm{Nm}^{3} \mathrm{~kg}_{\mathrm{TVS}}{ }^{-}$ 1 and $0.016 \mathrm{Nm}^{3} \mathrm{kgTVS}^{-1}$ obtained in our study (Table 4). Athanasoulia et al. (2012) obtained a methane yield of $0.814 \mathrm{Nm}^{3} \mathrm{kgTVS}^{-1}$ for blends of OMW (30\%) and waste activated sludge with hydraulic retention times between 12.3 and 19.7 days under mesophilic conditions. However, Kougias et al. (2010) and Athanasoulia et al. (2012) did not report the concentration of PPs in the tested OMW and thus the possible inhibiting effects of these compounds in their study cannot be compared with those of our study. However, both papers reported the inhibiting effects of VFA on methane yields in blends with $40 \%$ of OMW.

Sampaio et al. (2011) reported a methane yield of up to $2.12 \mathrm{~L}$ $\mathrm{L}^{-1} \mathrm{~d}^{-1}$ under mesophilic conditions, with blends of OMW and pig farm effluents; therefore, the methane yield obtained is much higher than those obtained in this study. However, the yields reported in Sampaio et al. (2011) were achieved by progressively increasing the OMW content in the blend from 0 to $83 \%$; thus the microorganisms had a very slow adaptation phase (232 days) to a PPs concentration of $3.59 \mathrm{~g} \mathrm{~L}^{-1}$.

Therefore, our first three tests showed that for blends containing OMW, it is suitable to reduce the concentrations of PPs and VFA below the inhibiting concentrations of 0.6-1 $\mathrm{g} \mathrm{L}^{-1}$ and 1.9-2.0 $\mathrm{g} \mathrm{L}^{-1}$, respectively, by diluting OMW properly (in our study OMW content of or below $20 \%$ was found to be suitable). This avoids issues of limited biodegradability of blends with high concentrations of PPs and VFA.

\section{Blends of digested liquid manure, olive mill wastewater, and cit- rus peel}

The methane yield of the blend of digestate and citrus residues (DLM $(80 \% \mathrm{v} / \mathrm{v}) / \mathrm{CP}(20 \% \mathrm{v} / \mathrm{v}))$ was $6.50 \mathrm{NL} \mathrm{L}^{-1}$ (corresponding to $0.106 \mathrm{Nm}^{3} \mathrm{kgTVS}^{-1}$ ) after 25 days (Tables 3 and 4 ). The d-limonene content in $\mathrm{CP}$ was $0.95 \mathrm{~g} \mathrm{~kg}^{-1}$ ( $95 \%$ of EO concentration, equal to $1 \mathrm{~g} \mathrm{~kg}^{-1}$, Table 2), $\mathrm{pH}$ (6.9, Table 2) was always in the optimal range of 6.5-8.5 (Martinez-Garcia et al., 2009; Gonzàles-Gonzàles and Cuadros, 2015), and the VFA concentration $\left(0.7 \mathrm{~g} \mathrm{~L}^{-1}\right.$, Table 2) was below the inhibiting concentration $\left(2.0 \mathrm{~g} \mathrm{~kg}^{-1}\right)$. Martín et al. (2010) reported an EO content of about $5.5 \mathrm{~g} \mathrm{~kg}^{-1}$ in orange peel,
90\% of which was d-limonene (Hull et al., 1953; Braddock et al., 1986). Therefore, the content of d-limonene in orange peel is about $4.9 \mathrm{~g} \mathrm{~kg}^{-1}$. Considering that the content of d-limonene, which inhibits anaerobic digestion, was reported to be about $0.6 \mathrm{~g} \mathrm{~kg}^{-1}$ by Forgács (2012) and Wikandari et al. (2014), it is evident that in our test this value was exceeded $\left(1.0 \mathrm{~g} \mathrm{~kg}^{-1}\right.$ of EO in DLM $(80 \%$ $\mathrm{v} / \mathrm{v}) / \mathrm{CP}(20 \% \mathrm{v} / \mathrm{v})$ blend, Table 2$)$. Therefore, the methane production in our study was lower than that reported by other researchers who used citrus peel after d-limonene extraction. As a matter of fact, Martín et al. (2010) obtained a methane yield of $0.230 \mathrm{Nm}^{3}$ $\mathrm{kgTVS}^{-1}$ under mesophilic conditions in blends containing CP, from which $70 \%$ of d-limonene was previously extracted. Forgács (2012) observed methane yields of $0.54 \mathrm{Nm}^{3} \mathrm{kgTVS}^{-1}$ and $0.1 \mathrm{Nm}^{3}$ $\mathrm{kgTVS}^{-1}$ from d-limonene extracted $\mathrm{CP}$ and untreated $\mathrm{CP}$, respectively. Nguyen (2012) recorded a methane yield of $0.061 \mathrm{Nm}^{3}$ $\mathrm{kgTVS}^{-1}$ with a blend of $20 \%$ untreated CP and $80 \%$ inoculum from other biomasses (in spite of the low concentration of d-limonene in the experimental blend). This methane yield increased to 0.217 $\mathrm{Nm}^{3} \mathrm{~kg}_{\mathrm{TVS}}{ }^{-1}$ when the substrate was previously treated using $\mathrm{n}$ hexane as a solvent. Therefore, the theoretical methane yield of CP, reported to be $0.45 \mathrm{Nm}^{3} \mathrm{kgTVS}^{-1}$ by Wikandari et al. (2014), can be achieved only if d-limonene is extracted from CP to lower its concentration below the inhibiting concentration of $0.6 \mathrm{~g} \mathrm{~kg}^{-1}$.

The last mesophilic test [DLM (70\% v/v)/OMW (20\% v/v)/CP $(10 \% \mathrm{v} / \mathrm{v})]$ was carried out to investigate possible inhibiting effects of PPs and EO. In this blend, the EO concentration was reduced by $50 \%$ of its inhibiting concentration, reported above, to avoid inhibiting effects of PPs and EO. The methane yield of the DLM $(70 \% \mathrm{v} / \mathrm{v}) / \mathrm{OMW}(20 \% \mathrm{v} / \mathrm{v}) / \mathrm{CP}(10 \% \mathrm{v} / \mathrm{v})$ blend $\left(0.099 \mathrm{Nm}^{3}\right.$ $\mathrm{kgTVS}^{-1}$ after 25 days, Table 4) was much lower than that of DLM $(80 \% \mathrm{v} / \mathrm{v} / \mathrm{OMW}(20 \% \mathrm{v} / \mathrm{v})$, but similar to that of DLM $(80 \%$ $\mathrm{v} / \mathrm{v}) / \mathrm{CP}(20 \% \mathrm{v} / \mathrm{v})$. This blend contains $70 \%$ of DLM, $20 \%$ of OMW, and $10 \%$ of CP, with concentrations of PPs and EO (Table 2, $0.6 \mathrm{~g} \mathrm{~L}^{-1}$ of PPs and $0.5 \mathrm{~g} \mathrm{~kg}^{-1}$ of EO) just below the respective inhibiting concentrations reported above $\left(0.8 \mathrm{~g} \mathrm{~L}^{-1}\right.$ for PPs and 0.6 $\mathrm{g} \mathrm{kg}^{-1}$ for EO). However, the presence of d-limonene in CP even at a concentration of $0.5 \mathrm{~g} \mathrm{~kg}^{-1}$ had a noticeable inhibiting effect on the OMW blend containing PPs below its inhibiting concentration. Since the $\mathrm{pH}$ was optimal (6.9) and VFA initial concentration (1.7 $\left.\mathrm{g} \mathrm{L}^{-1}\right)$ was below the inhibiting concentration $\left(2.0 \mathrm{~g} \mathrm{~L}^{-1}\right)$

Table 4. Total biogas and methane yields under standard conditions (T: $0^{\circ} \mathrm{C}, \mathrm{P}: 1013 \mathrm{hPa}$ ) (in $\mathrm{Nm}^{3} \mathrm{kgTVS}^{-1}$ ) in the blends tested under mesophilic and thermophilic anaerobic digestion.

\begin{tabular}{|c|c|c|c|c|}
\hline \multirow[t]{2}{*}{ Blend } & \multicolumn{2}{|c|}{ Total biogas yield $\left(\mathrm{Nm}^{3} \mathrm{kgTVS}^{-1}\right)$} & \multicolumn{2}{|c|}{ Total methane yield $\left(\mathrm{Nm}^{3} \mathrm{kgTVS}^{-1}\right)$} \\
\hline & After 15 days & After 25 days & After 15 days & After 25 days \\
\hline \multicolumn{5}{|c|}{ Mesophilic conditions $\left(37^{\circ} \mathrm{C}\right)$} \\
\hline DLM50/0MW50 & $0.072^{\mathrm{a}}$ & $0.073^{\mathrm{a}}$ & $0.016^{\mathrm{a}}$ & $0.016^{\mathrm{a}}$ \\
\hline DLM70/OMW30 & $0.171^{b}$ & $0.176^{b}$ & $0.066^{\mathrm{b}}$ & $0.067^{b}$ \\
\hline DLM80/OMW20 & $0.239^{\mathrm{cA}}$ & $0.362^{\mathrm{cA}}$ & $0.109^{\mathrm{cA}}$ & $0.187^{\mathrm{cA}}$ \\
\hline DLM80/CP20 & $0.194^{\mathrm{cA}}$ & $0.208^{\mathrm{cA}}$ & $0.097^{\mathrm{cA}}$ & $0.106^{\mathrm{cA}}$ \\
\hline DLM70/OMW20/CP10 & $0.168^{\mathrm{dA}}$ & $0.183^{\mathrm{dA}}$ & $0.088^{\mathrm{dA}}$ & $0.099 \mathrm{dA}$ \\
\hline \multicolumn{5}{|c|}{ Thermophilic conditions $\left(52^{\circ} \mathrm{C}\right)$} \\
\hline DLM80/OMW20 & $0.100^{\mathrm{aB}}$ & $0.109^{\mathrm{aB}}$ & $0.063^{\mathrm{aB}}$ & $0.069^{\mathrm{aB}}$ \\
\hline DLM80/CP20 & $0.105^{\mathrm{aB}}$ & $0.118^{\mathrm{aB}}$ & $0.062^{\mathrm{aB}}$ & $0.070^{\mathrm{aB}}$ \\
\hline DLM70/OMW20/CP10 & $0.050^{\mathrm{bB}}$ & $0.069^{\mathrm{bB}}$ & $0.026^{\mathrm{bB}}$ & $0.036^{\mathrm{bB}}$ \\
\hline
\end{tabular}

DLM, digested liquid manure; OMW, olive mill wastewater; $\mathrm{CP}$, citrus peel. Different superscript letters indicate significant differences between the tests under the same temperature conditions at $\mathrm{P}<0.05$, while capital superscript letters refers to significant differences between the same tests under different temperature conditions at $\mathrm{P}<0.05$. 
(Table 2), under mesophilic conditions, a synergic inhibiting effect of PPs in OMW and EO in CP on microbial growth may exist.

Decreasing methane production rates were recorded after 15 days for DLM $(80 \% \mathrm{v} / \mathrm{v}) / \mathrm{CP}(20 \% \mathrm{v} / \mathrm{v})$ and DLM $(70 \%$ $\mathrm{v} / \mathrm{v}) / \mathrm{OMW}(20 \% \mathrm{v} / \mathrm{v}) / \mathrm{CP}(10 \% \mathrm{v} / \mathrm{v})$ potentially due to presence of inhibiting compounds (such as PPs and/or EO). The volume of methane produced from these blends after 25 days was only $10 \%$ higher than that in the first 15 days (Table 3 ). The daily biogas and methane production rates increased during the first few days (presumably due to progressive microbial adaptation to the inhibiting compounds), with a peak in biogas production rates on the $5^{\text {th }}$ day and subsequent drastic reductions (Figure 2).

The methane yields of the blends containing CP, OMW (at $20 \% \mathrm{v} / \mathrm{v})$, and CP + OMW were compared. Since the DLM $(80 \%$ $\mathrm{v} / \mathrm{v}) / \mathrm{OMW}(20 \% \mathrm{v} / \mathrm{v})$ and DLM (70\% v/v)/OMW (20\% v/v)/CP $(10 \% \mathrm{v} / \mathrm{v})$ blends showed methane yields higher than that of DLM $(70 \% \mathrm{v} / \mathrm{v}) / \mathrm{OMW}(30 \% \mathrm{v} / \mathrm{v})$ (Table 4$)$, we may deduce that the addition of $10 \%$ of OMW induces higher inhibition than the addition of $10 \%$ of CP. Conversely, the methane yield of the DLM $(80 \% \mathrm{v} / \mathrm{v}) / \mathrm{CP}(20 \% \mathrm{v} / \mathrm{v})$ blend was lower since the EO concentra-
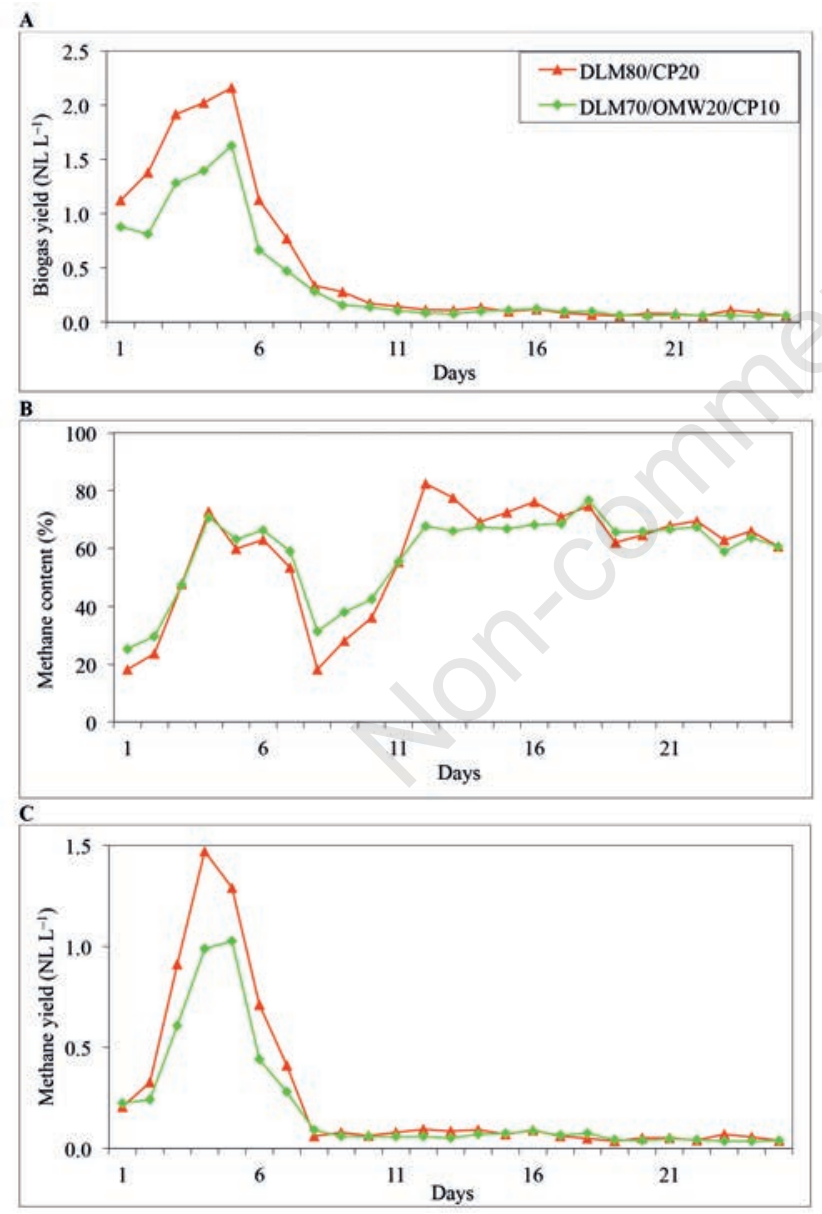

Figure 2. Biogas yield (A), methane content in biogas (B), and methane yield $(C)$ under standard conditions (T: $\left.0^{\circ} \mathrm{C}, \mathrm{P}: 1013 \mathrm{hPa}\right)$, from anaerobic digestions of different blends containing OMW and/or CP under mesophilic conditions $\left(37^{\circ} \mathrm{C}\right)$. The number after the substrate indicates its percentage in the blend volume: $\%(v / v)$. tion was above the inhibiting concentration thereby resulting in stronger inhibiting effects

\section{Thermophilic tests}

Compared to the experimental tests conducted under mesophilic conditions, the experimental tests performed at $52^{\circ} \mathrm{C}$ showed large reductions in methane production $[-61 \%$ for DLM $(80 \% \mathrm{v} / \mathrm{v}) / \mathrm{OMW}(20 \% \mathrm{v} / \mathrm{v}),-32 \%$ for DLM $(80 \% \mathrm{v} / \mathrm{v}) / \mathrm{CP}(20 \%$ $\mathrm{v} / \mathrm{v})$, and $-66 \%$ for DLM $(70 \% \mathrm{v} / \mathrm{v}) / \mathrm{OMW}(20 \% \mathrm{v} / \mathrm{v}) / \mathrm{CP}(10 \%$ $\mathrm{v} / \mathrm{v})]$. Moreover, the methane produced from DLM $(70 \%$ $\mathrm{v} / \mathrm{v}) / \mathrm{OMW}(20 \% \mathrm{v} / \mathrm{v}) / \mathrm{CP}(10 \% \mathrm{v} / \mathrm{v})$ in the last ten days was less than $28 \%$ of the total production (Table 4 ); therefore, it is evident that prolonging digestion beyond 10-15 days is not suitable (Figure 3). This may be because thermophilic anaerobic digestion processes are more sensitive to the presence of inhibiting compounds such as PPs, VFA, and/or EO than mesophilic anaerobic digestion processes. Studies have shown that thermophilic digestion processes have lower degradation efficiencies of phenolic compounds (Levén and Schnürer, 2005; Fezzani and Ben Cheikh, 2007), which decreases methane production rates, than mesophilic digestion processes.
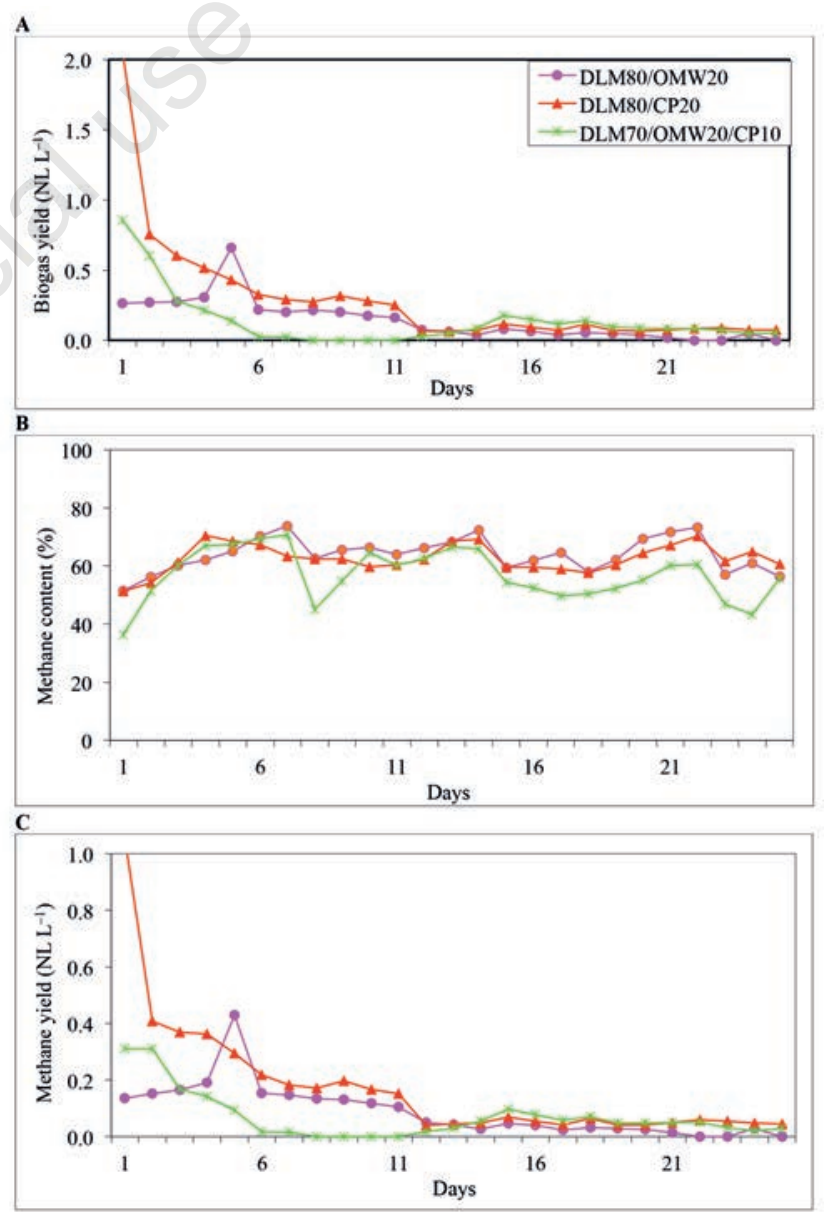

Figure 3. Biogas yield (A), methane content in biogas (B), and methane yield (C) under standard conditions (T: $0^{\circ} \mathrm{C}$, P: 1013 $\mathrm{hPa}$ ), from anaerobic digestions of different blends under thermophilic conditions $\left(52^{\circ} \mathrm{C}\right)$. The number after the substrate indicates its percentage in the blend volume: $\%(v / v)$. 
Moreover, Levén and Schnürer (2005) ascertained that when the internal temperature of thermophilic batch-reactors decreases, phenolic compounds that are resistant at a temperature of $55^{\circ} \mathrm{C}$ are degraded.

The methane yields of the three blends tested in our study [DLM (80\% v/v)/OMW (20\% v/v), DLM (80\% v/v)/CP (20\% v/v), and DLM (70\% v/v)/OMW (20\% v/v)/CP $(10 \% \mathrm{v} / \mathrm{v})]$, with concentrations of toxic compounds (VFA, PPs, and/or EO) close (just below or above) to the respective inhibiting concentrations, at $52^{\circ} \mathrm{C}$ were always lower than the methane yields at $37^{\circ} \mathrm{C}$. This means that the inhibiting effects of these toxic compounds on microbial growth are lower under mesophilic conditions than under thermophilic conditions. Therefore, we can conclude that the synergic inhibiting effects of PPs and EO in DLM $(70 \%$ $\mathrm{v} / \mathrm{v}) / \mathrm{OMW}(20 \% \mathrm{v} / \mathrm{v}) / \mathrm{CP}(10 \% \mathrm{v} / \mathrm{v})$, under thermophilic conditions, were enhanced since the methane produced from this blend $\left(0.036 \mathrm{Nm}^{3} \mathrm{kgTvs}^{-1}\right)$ is much lower than that from the DLM $(80 \%$ $\mathrm{v} / \mathrm{v}) / \mathrm{OMW}(20 \% \mathrm{v} / \mathrm{v})$ and DLM (80\% v/v)/CP (20\% v/v) blends (0.069 and $0.070 \mathrm{Nm}^{3} \mathrm{~kg}_{\mathrm{TVS}^{-1}}$ ) (Table 4). This was not observed under mesophilic conditions.

\section{Conclusions}

This study contributes towards gaining a better understanding of the biochemical processes in anaerobic digestion of OMW by evaluating, under mesophilic and thermophilic conditions, the influence of inhibiting substances PPs, VFA, and EO on methane yields.

Low methane yields were observed in blends with OMW content higher than $20 \%$ due to high concentrations of PPs and VFA. Addition of other substrates (such as citrus peel) may induce synergic inhibiting effects of PPs and EO (concentration of EO higher than $0.5 \mathrm{~g} \mathrm{~kg}^{-1}$ ) on microbial growth. These effects are more evident under thermophilic conditions than under mesophilic conditions.

The methane yields under thermophilic conditions were significantly lower than those under mesophilic conditions. This confirms that thermophilic processes are more sensitive to the presence of inhibiting compounds. Biogas production was negligible after 15 days both under mesophilic and thermophilic conditions.

Considering the results of this study, reduction of PPs, VFA, and EO concentrations in blends subjected to anaerobic co-digestion below the inhibiting concentrations of $0.6 \mathrm{~g} \mathrm{~L}^{-1}, 2 \mathrm{~g} \mathrm{~L}^{-1}$, and $0.5 \mathrm{~g} \mathrm{~kg}^{-1}$, respectively, is recommended to avoid toxic effects of these compounds on the growth of microorganisms, which results in very low methane yields. This implies that the contents of OMW and/or CP, particularly when these residues are used together in the digester feed, needs to be reduced.

\section{References}

Angelidaki I., Ahring B.K. 1997. Co-digestion of olive mill wastewaters with manure, household waste or sewage sludge. Biodegradation. 8:221-6.

APHA (American Public Health Association). 1998. Standard Methods for the Examination of Water and Wastewater. 20 $0^{\text {th }}$ Ed. American Public Health Association, American Water Works Association and Water Environmental Federation, Washington, DC, USA.

Appels L., Baeyens J., Degreve J., Dewil R. 2008. Principles and potential of the anaerobic digestion of waste-activated sludge.
Prog. Energ. Combust. 34:755-81.

Athanasoulia E., Melidis P., Aivasidis A. 2012. Anaerobic waste activated sludge co-digestion with olive mill wastewater. Water Sci. Technol. 65:2251-7.

Bernardi B., Benalia S., Zema D.A., Tamburino V., Zimbalatti G. 2017. An automated medium scale prototype for anaerobic codigestion of olive mill wastewater. Inform. Process. Agric. 4:316-20.

Borja R., Banks J.C., Alba J., Maestro R. 1996. The effect of the most important phenolic constituents of OMW on batch anaerobic methanogenis. Environ. Technol. 17:167-74.

Borja R., Raposo F., Rincon B. 2006. Treatment technologies of liquid and solid wastes from two-phase olive oil mills. Grasas Aceites. 57:32-46.

Braddock R.J., Temelli F., Cadwallader K.R. 1986. Citrus essential oils - a dossier for material safety data sheets. Food TechnolChicago. 40:114-6.

Dinuccio E., Balsari P., Gioelli F., Menardo S. 2010. Evaluation of the biogas productivity potential of some Italian agro-industrial biomasses. Bioresource Technol. 101:3780-3.

Escher B.I., Snozzi M., Schwarzenbach R.P. 1996. Uptake, speciation, and uncoupling activity of substituted phenols in energy transducing membranes. Environ. Sci. Technol. 30:3071-9.

Fedorak P.M., Hrudey S.E. 1984. The effects of phenols and some alkil phenolics on batch anaerobic methanogenesis. Water Resour. 18:361-7.

Fezzani B., Ben Cheikh R. 2007. Thermophilic anaerobic codigestion of olive mill wastewater with olive mill solid wastes in a tubular digester. Chem. Eng. J. 132:195-203.

Folin G. 1927. Tyrosine and tryptophan determinations in proteins. J. Biol. Chem. 73:627-50.

Forgács G. 2012. Biogas Production from Citrus Wastes and Chicken Feather: Pretreatment and Co-digestion. Thesis for the Degree of Doctor of Philosophy, Chalmers University of Technology, Göteborg, Sweden.

Gelegenis J., Georgakakis D., Angelidaki I., Christopoulou N., Goumenaki M. 2007. Optimization of biogas production from olive-oil mill wastewater by codigesting with diluted poultrymanure. Appl. Energ. 84:646-63.

Gonzàles-Gonzàles A., Cuadros F. 2015. Effect of aerobic pretreatment on anaerobic digestion of olive mill wastewater (OMWW): An eco-efficient treatment. Food Bioprod. Process. 95:339-45.

Hull W.Q., Lindsay C.W., Baier W.E. 1953. Chemicals from oranges. Ind. Eng. Chem. 45:876-90.

Kougias P.G., Kotsopoulos T.A., Martzopoulos G.G. 2010. Anaerobic co-digestion of pig waste with olive mill wastewater under various mixing conditions. Fresen. Environ. Bull. 19:1682-6.

Kougias P.G., Kotsopoulos T.A., Martzopoulos G.G. 2014. Effect of feedstock composition and organic loading rate during the mesophilic co-digestion of olive mill wastewater and swine manure. Renew. Energ. 69:202-7.

Levén L., Schnürer A. 2005. Effects of temperature on biological degradation of phenols, benzoates and phthalates under methanogenic conditions. Int. Biodeter. Biodegr. 55:153-60.

Martín M.A., Siles J.A., Chica A.F., Martín A. 2010. Biomethanisation of orange peel waste. Bioresource Technol. 101:8993-9.

Martinez-Garcia G., Johnson A.C., Bachmann R.T., Williams C.J., Burgoyne A., Edyvean R.G.J. 2009. Anaerobic treatment of olive mill wastewater and piggery effluents fermented with Candida tropicalis. J. Hazard. Mater. 164:1398-405. 
Nguyen H. 2012. Biogas Production from Solvent Pretreated Orange Peel. Master of Science Thesis in the Master's Program MPISC, Chalmers University of Technology, Göteborg, Sweden.

Sampaio M.A., Goncalves M.R., Marques I.P. 2011. Anaerobic digestion challenge of raw olive mill wastewater. Bioresource Technol. 102:10810-8.

Scott W.C., Veldhuis M.K. 1966. Rapid estimation of recoverable oil in citrus juices by bromate titration. J. Assoc. Off. Anal. Chem. 49:628-33.

Siegert I., Banks C. 2005. The effect of volatile fatty acid additions on the anaerobic digestion of cellulose and glucose in batch reactors. Process Biochem. 40:3412-8.

VDI 4630, 2006. Fermentation of organic materials,
Characterisation of Substrate, Sampling, Collection of Material Data, Fermentation Tests. VDI, Gesellschaft, Energietechnik.

Wikandari R., Millati R., Nur Cahyanto Taherzadeh M.J. 2014. Biogas Production from Citrus Waste by Membrane Bioreactor. Membranes. 4:596-607.

Yi J., Dong B., Jin J., Dai X. 2014. Effect of Increasing Total Solids Contents on Anaerobic Digestion of Food Waste under Mesophilic Conditions: Performance and Microbial Characteristics Analysis. Plos One. 9:e102548.

Zema D.A. 2017. Planning the optimal site, size, and feed of biogas plants in agricultural districts. Biofuel. Bioprod. Bior. $11: 454-71$. 